\title{
Social Structure of Mizo Village: a Participatory Rural Appraisal
}

\author{
Lalhmunmawia and Samares Kumar Das*
}

Dept. of Veterinary \& Animal Husbandry Extension, College of Veterinary Sciences \& Animal Husbandry, Central Agricultural University, Selesih, Aizawl, Mizoram (796 015), India

\section{Corresponding Author}

Samares Kumar Das

e-mail: samcau.d1@gmail.com

\author{
Article History \\ Article ID: AR1899 \\ Received in $14^{\text {th }}$ September, 2018 \\ Received in revised form 21 ${ }^{\text {st }}$ February, 2019 \\ Accepted in final form 27 $7^{\text {th }}$ February, 2019
}

\begin{abstract}
Mizoram in india, the land of Mizo, is the fifth smallest state in India with the highest tribal population. However, there is a dearth of in depth study on social structure of Mizo village. This calls for a better understanding of social structure for planning and implementation of location specific research and development programs. Keeping this in view, a field study was carried out in a purposively selected village named Muthi in Aizawl district of Mizoram to study the social structure through Participatory Rural Appraisal (PRA) to help R\&D professionals to plan and implement location specific development programs. Case study was done following the principles and methods of PRA. Data collected through PRA were analyzed and reported through the principles and methods of PRA. Established in 1910, Muthi was a village with three localities. Supply and services included road, path, stair steps, spring, cemetery, community hall, shop, post office, playing ground, and a number of institutions and organisations. Among institutions in the village, Church and Young Mizo Association were most important. Houses were constructed on the top and slope of the hill along the road. Traditionally, houses were rectangular in shape with thatched roof and walls made of weaved bamboo or timber frames with bamboo mat floor, which did not exist at present. Water scarcity was the most important problem in the village which should be solved first.
\end{abstract}

Keywords: Social structure, Mizoram, Mizo village, PRA

\section{Introduction}

Mizoram is the fifth smallest state in India with a geographical area of $21,081 \mathrm{sq} \mathrm{km}$ inhabited by the people called "Mizo" (Haokip, 2018). The geography of the state is hilly with few plain areas. The state shares its boundary with Manipur, Assam and Tripura. The international boundary comprises the major part of the state border, sharing $404 \mathrm{~km}$ with Myanmar and $318 \mathrm{~km}$ with Bangladesh. According to 2011 Census, Mizoram had a population of 10,91,014 making it the second lowest populous state in the country. The capital (Aizawl) is inhabited by $37 \%$ of the state's total population, making it one with the highest number of people residing in urban areas. Of all the states in the country, it also has the highest tribal population, $94.4 \%$ of the total population (Roluahpuia, 2016). Rural society has a form, a structure, like a building. This structure consists of a tangible form called the "physical structure" and an intangible form called the "social structure". Together the physical and social structure forms the structure of rural society within which the people live. These structures govern their behaviour, thinking, attitudes, values, motivations and actions. With this understanding, implementation of an effective strategy for promoting development can be undertaken (Chitambar, 1997). However, there is a dearth of in-depth study on social structure of Mizo village. This calls for a better understanding of social structure for planning and implementation of location specific research and development programmes in realistic lines. Keeping this in view, a research study was undertaken to study the "physical structure" of the village in Mizoram.

\section{Materials and Methods}

Field study was carried out in a purposively selected village named Muthi in Aizawl district of Mizoram in February, 2017. The village was located two-km away from the main road towards Thuampui, and $13 \mathrm{~km}$ from Aizawl city. The condition of the two-km approach road to the village was not good which becomes worse during rainy season. Case study was done following the principles and methods of Participatory Rural Appraisal (PRA). Case study is a method of in-depth inquiry of a social unit, i.e. an individual, family, organization, institution, social group or entire community. It allows to retain the meaningful characteristic of real life events with an emphasis on qualitative than quantitative aspects (Yin, 1993). PRA is a group of approaches, methods and behaviours that enable people to express and analyze the realities of their lives and conditions. It provides an alternative method of 
data collection and analysis with an emphasis on qualitative than quantitative information (Chambers, 1983; Mukherjee, 1993; Pretty, 1995; Reddy, 1999). There are different aspects of rural life not all of which can be measured quantitatively. Some of them can be quantified, some are better described qualitatively while some others remain hidden and elusive. A relative ranking and scoring of issues can enable relative comparisons without absolute measurements (Mukherjee, 1993). Data collected through PRA were analyzed and reported following the principles and methods of PRA.

\section{Results and Discussion}

\subsection{About the village}

Established in 1910, Muthi was a village under Tlangnuam block in Aizawl district of Mizoram. As per 2011 census, the village had a total population of 892 ( 457 male and 435 female) who were Christian by religion. The village was well known for its achievement in football in Mizoram. There were two legends concerning the name of the village. One legend was that the village was named after the "Muthi" tree. Once upon a time, the village was full of Muthi tree. At present there were only a few Muthi tree in the village. Muthi trees were cut down excessively for firewood, furniture, etc. Other legend was that the village got its name from the bird "Murra" (a big eagle) which died on the hill. Once upon a time, there lived two Murra eagles on the hill top migrated from the east. They were male and female. They lived for many years until they died. Consequently, people named the village Muthi, place where eagle died. The village had a primary school established in 1928, a middle school established in 1987 and a high school established in 1996. The village was electrified in 1986. Except rain water harvested during rainy season, springs (Tuikhur) were the main sources of water for the villagers. There were three types of perennial springs: Manapa lui tuikhur, Sihpui tuikhur and Sakhi tuikhur, and two types of seasonal springs: Lamhnai tuikhur and Zo kawng tuikur in the village. Perennial springs supplied water round the year, whereas seasonal springs supplied water only during rainy season.

\subsection{Structure of the village}

PRA method of mapping was used to study physical structure of the village. The village was divided into three localities: Vengthlang, Venglai and Vengthar, as recognised by the villagers. Map 1 shows the residential area, road, field, playing ground, community hall, school, health centre, post office, church, forest and natural resources.

\subsection{Pattern of settlement}

Human settlement had a pattern, a structure which had profound influence on the life and livelihood of the villagers (Chitambar, 1997). In the study village, houses were constructed on the top and slope of the hill along the road using wood and bamboo. Houses constructed on the hill slope had a base with wooden pillars at a level parallel or slightly higher than the road. Traditionally, the Mizo houses were

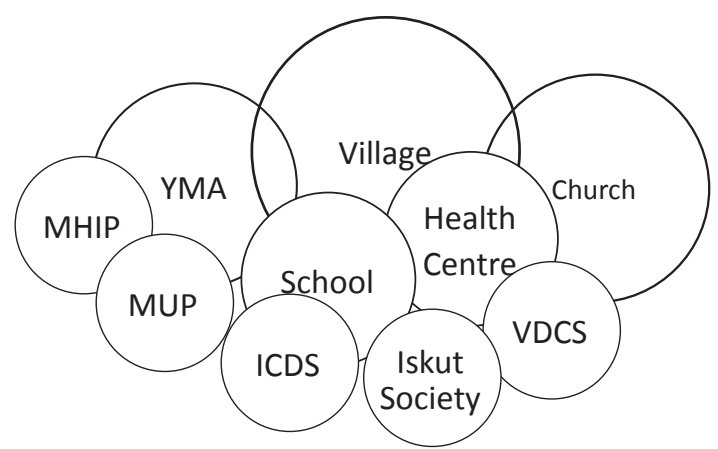

Figure 1: Venn diagram on organizations and institutions in the village

rectangular in shape with thatched roof ( $D i$, i.e. straw) and walls made of weaved bamboo or timber frames and bamboo mat floor. But there were no such houses to be seen in the village nowadays. Thatched roof were replaced by tin roof, weaved bamboo walls with tiles, and bamboo mat floor with wooden plank floor. Most of the houses in the village were of Assam type with few cement-concrete houses and only a few houses were made of traditional bamboo wall, but with tin roof.

\subsection{Household}

A case study of a widow woman-headed household is presented below.

Pi Laikungi, the head of the household, was a 73-year old widow with primary education. She could read and write in Mizo. Her husband passed away in 2009. She lived with her grandson who was studying in class IX at a middle school in the village. Every Sunday she participated in morning church service. With an Assam type dwelling house she possessed 4 tin farm lands: 1 tin near and 3 tin away from home ( 1 tin=3 bigha, 2.5 tin=1 ha). She also reared two pigs: one Zo vawk (Mizo pig) and another crossbred provided by her granddaughter who lived in Durtlang (a town nearby). Pigs would be reared up to about one-year with $80 \mathrm{~kg}$ body weight and would be sold by his son who lived in the village. She woke up at $5 \mathrm{am}$, swept the floor and prepared breakfast. After taking breakfast she fed the pigs, and went to the field after washing the utensils. If she went to nearby farm she would come back home around 12 noon for lunch and went to the farm again. She collected firewood while returning from the farm. When went far away farm, she carried lunch with her and came back around $5 \mathrm{pm}$. Back home she fed her pigs, and prepared dinner. She usually had dinner between 6 and $6.30 \mathrm{pm}$. After that she cooked feed for pigs, usually on alternate days. Then she took rest, read weekly church newsletter and went to bed at $9 \mathrm{pm}$. She cultivated brinjal, pumpkin, cucumber, chilli, bean, mustard, cabbage, Thingthupui (Dysoxylum gobara) in her farm. If harvested surplus, she sold it to the middlemen in the village to be sold at Thuampui or Bawngkawn market. Her grandson occasionally cut log of trees died or fallen in the field and 
forest. He hired a pick-up van from the village at $₹ 400$, and sold wood at ₹ 5 per log of wood (2.5-3 ft long). She had no cash income as such. Her daughter and son living in the village took care of her medical and other expenditure in times of need.

\subsection{Organizations and institutions}

Following were the institutions and organizations existing in the village which are arranged as per their need and importance to the villagers in descending order: Church $>\mathrm{YMA}>\mathrm{School}>\mathrm{Health}$ centre $>$ Anganwadi (ICDS) $>$ MUP $>$ MHIP $>$ Iskut Society $>$ Village Dairy Cooperative Society (VDCS).

A Venn diagram drawn on the organizations and institutions in the village (Figure 1) reveals that church was the largest religious institution in the village. There were three churches in the village: Presbyterian, Roman Catholic and Pentecostal. All the villagers belonged to a church of one or the other order. Young Mizo Association (YMA) was the largest voluntary association in the village. Boys and girls above 14 years were the members. The association was engaged in various welfare activities and all round development of the village. In case of death of any person in the village YMA members remained awake throughout the night consoling the bereaved family singing the songs of lamentations. On the next day early morning, the young men went to cemetery to dig grave for burial of the dead and carry the dead body to the grave. At night the young men slept in the house of the bereaved family for consolation. There were four schools in the village: three government sponsored (primary, middle and high) and one private middle school. These schools served the educational purpose of the villagers. There was one government health sub-center in the village catering to the primary health care needs of the villagers. There were two Anganwadi (Integrated Child Development Scheme, ICDS) centres in the village catering to the needs of children. Besides, there were two associations in the village: Mizo Upa Pawl (MUP) for the old men and Mizo Hmeichhe Insuihkhawm Pawl (MHIP) for girls and women (young and old). Besides, there was an Iskut

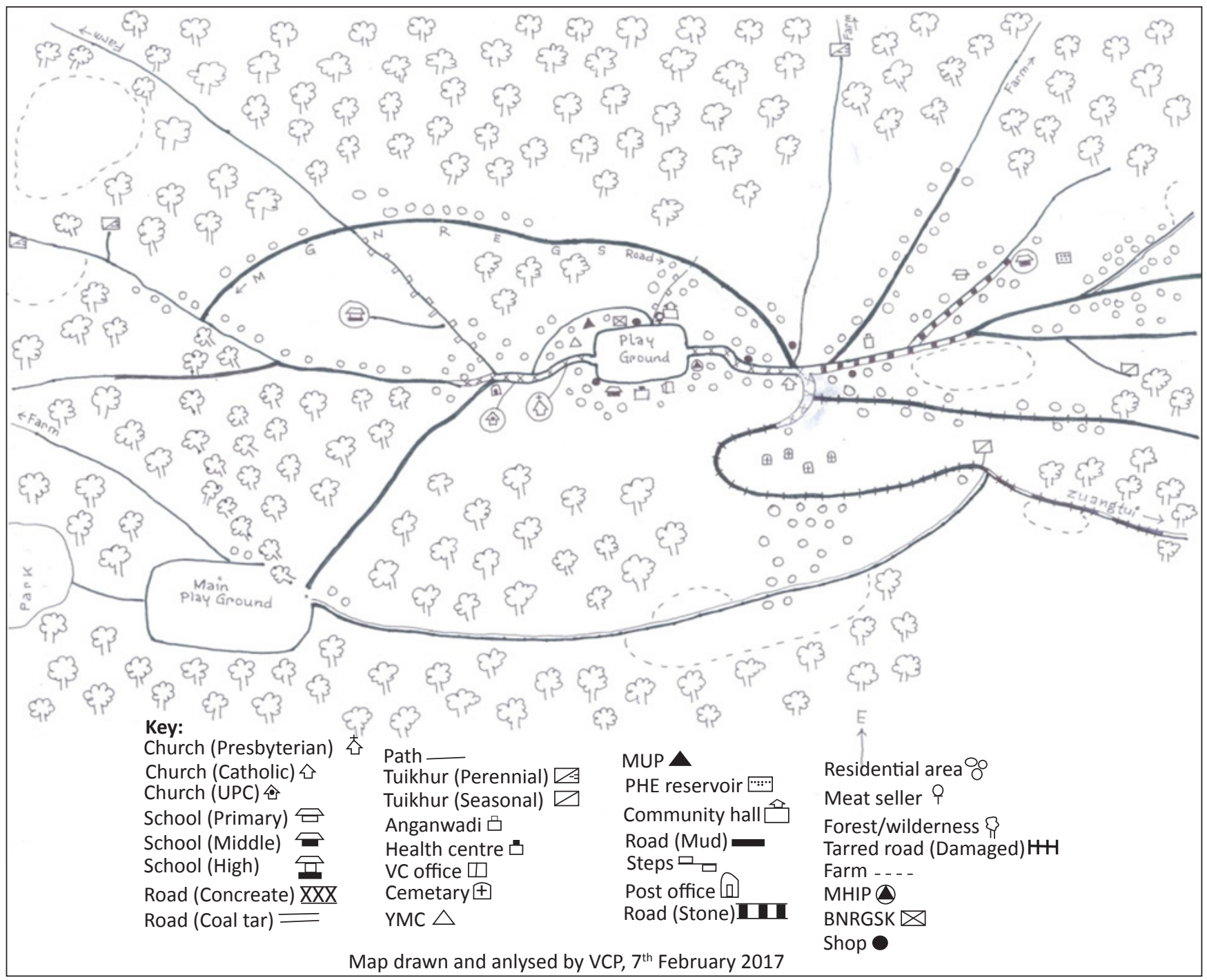

Map 1: Social-cum-resource map of Muthi village 
Society in the village for the welfare of the Iskut (squash) farmers, and a Village Dairy Cooperative Society (VDCS) for dairy farmers.

\section{Conclusion}

Established in 1910, Muthi was divided in three localities. Supply and services included road, path, spring, cemetery, community hall, shop, post office, playing ground, and institutions and organisations. Among institutions, Church and Young Mizo Association were most important. Houses were constructed on the top and slope of the hill. Traditionally, houses were rectangular in shape with thatched roof and walls made of weaved bamboo or timber frames with bamboo mat floor, not seen at present.

\section{References}

Chambers, R., 1983. Rural development: Putting the last first. Pearson Education, New Delhi.

Chitambar, J.B., 1997 Introductory rural sociology ( $\left.2^{\text {nd }} \mathrm{Ed}\right)$.
New Age International Publishers, New Delhi.

Haokip, Pauthang., 2018. Clans, tribes and unions of tribes: Nomenclature of North East India. Economic and Political Weekly, $1^{\text {st }}$ September, 61-66.

Mukherjee, N., 1993. Participatory rural appraisal: Methodology and applications. Concept Publishing Co., New Delhi.

Pretty, J.N., 1995. Regenerating agriculture: Policies and practice for sustainability and self-reliance. Vikas Publishing House Pvt. Ltd., New Delhi.

Reddy, V.R., 1999. 'Wealth Ranking' in socio-economic research: Substitute or complement? Indian Journal of Agricultural Economics 54(1), 93-103.

Roluahpuia., 2016. Ethnic tension in Mizoram: Contested claims, conflicting positions. Economic and Political Weekly, $16^{\text {th }}$ July, 21-25.

Yin, R.K., 1993. Applications of case study research. Applied Social Research Methods Series, Vol 34. Sage Publications, Newbury Park, California. 